\title{
Penerapan Higiene Personal pada Proses Penyembelihan Hewan Qurban di Masa Pandemi Covid 19 di Kabupaten Manokwari Provinsi Papua Barat
}

\author{
Edi Puwono ${ }^{1 *}$ \\ ${ }^{1}$ Politeknik Pembangunan Pertanian Yogyakarta Magelang \\ *Corresponding author: edipurwono1982@gmail.com
}

\begin{abstract}
Abstrak
Higiene personal adalah suatu tindakan untuk memelihara kebersihan dan kesehatan seseorang untuk kesejahteraan baik fisik maupun psikisnya. Perilaku higiene personal yang baik akan meminimalkan pintu masuk mikroorganisme sehingga dengan minimnya mikroorganisme diharapkan dapat meminimalkan resiko individu terkena penyakit. Tujuan penelitian ini adalah untuk mengetahui sejauh mana tingkat kepatuhan dan tingkat kesadaran masyarakat dalam melaksanakan dan menyikapi aturan yang telah dikeluarkan oleh pemerintah khususnya dalam hal penerapan higiene personal pada saat proses penyembelihan hewan qurban dimasa pandemik covid 19. Metode yang digunakan dalam penelitian ini adalah metode survei yang dilakukan di 30 Masjid yang ada di wilayah Kabupaten Manokwari dengan mengacu pada Surat Edaran Nomor. 0008. SE/PK.320/F/06/2020 tentang pelaksanaan kegiatan qurban dalam situasi wabah bencana nonalam Corona Virus Disease (Covid 19). Data yang diperoleh selanjutnya dianalisis secara deskriptif kuantitatif. Hasil penelitian menunjukkan bahwa sebagian besar masjid yang ada di wilayah Kabupaten Manokwari belum menerapkan aspek higiene personal pada saat proses penyembelihan hewan qurban dan saat penanganan daging qurban. Berdasarkan hasil penelitian dapat disimpulkan bahwa tingkat kepatuhan dan tingkat kesadaran masyarakat dalam melaksanakan dan menyikapi aturan yang telah dikeluarkan oleh pemerintah khususnya dalam hal penerapan higiene personal masih rendah.
\end{abstract}

Kata kunci: Higiene personal, Penyembelihan, Hewan qurban, Pandemi covid 19

\section{Abstract}

Personal hygiene is an action to maintain one's hygiene and health for both physical and psychological well-being. Good personal hygiene behavior will minimize the entrance to microorganisms so that the minimum number of microorganisms is expected to minimize the risk of individuals getting disease. The purpose of this study was to determine the level of compliance and the level of public awareness in implementing and responding to the regulations that have been issued by the government, especially in terms of the application of personal hygiene during the process of slaughtering qurban animals during the Covid 19 pandemic. The method used in this study is the survey method. Which was carried out in 30 mosques in the area of Manokwari Regency with reference to the Circular Number. 0008. SE / PK.320 / F / 06/2020 regarding the implementation of qurban activities in situations of a non-natural disaster outbreak of Corona Virus Disease (Covid 19). The data obtained were then analyzed descriptively quantitatively. The results showed that most of the mosques in Manokwari Regency had not applied personal hygiene aspects during the process of slaughtering qurban animals and when handling qurban meat. Based on the research results, it can be concluded that the level of compliance and the level of public awareness in implementing and responding to the regulations that have been issued by the government, especially in terms of the application of personal hygiene, are still low.

Key words: personal hygiene, slaughter, qurban animals, covid pandemic 19 
Prosiding Seminar Nasional Pembangunan dan Pendidikan Vokasi Pertanian Politeknik Pembangunan Pertanian Manokwari, 14 November 2020

e ISSN : 2774-1982

\section{PENDAHULUAN}

Hari Raya Idul Adha merupakan momen penting bagi umat muslim untuk menunaikan ibadah qurban di Manokwari khususnya dan di Indonesia pada umumnya. Ibadah qurban ditunaikan dengan melakukan pemotongan hewan berupa sapi dan kambing. Jenis sapi yang di sembelih atau diqurbankan di wilayah Manokwari secara keseluruhan adalah jenis sapi bali karena hanya jenis sapi inilah yang banyak dibudidayakan oleh masyarakat di daerah tersebut.

Pelaksanaan ibadah qurban dalam hal ini adalah pelaksanaan penyembelihan hewan qurban harus dilaksanakan sesuai dengan tuntunan syariat dan adab penyembelihan. Pada pelaksanaan penyembelihan hewan qurban tahun ini bangsa Indonesia bahkan dunia sedang dihadapkan dengan wabah pandemi Covid 19 yang kejadiannya hampir diseluruh Provinsi di Indonesia. Di Provinsi Papua Barat sendiri, pemerintah daerah setempat melalui Dinas Pertanian dan Ketahanan Pangan Kabupaten Manokwari telah memberikan informasi melalui surat edaran yang dikeluarkan oleh kepala dinas setempat tentang tata cara pelaksanaan pemyembelihan hewan qurban dimasa pandemik covid 19. Surat edaran tersebut mengacu pada surat dari Kementerian Pertanian Nomor. 0008. SE/PK.320/F/06/2020. Berdasarkan surat edaran tersebut hendaknya panitia penyelenggara, petugas ataupun masyarakat pada umumnya tidak mengabaikan aspekaspek yang tertuang pada surat edaran tersebut khususnya aspek higiene personal dalam proses pelaksanaan penyembelihan hewan qurban baik pada saat sebelum penyembelihan, pada saat proses penyembelihan maupun pada saat penanganan daging qurban.

Higiene adalah seluruh kondisi atau tindakan untuk meningkatkan kesehatan dengan cara memelihara dan melindungi kebersihan individu sedangkan higiene personal merupakan salah satu bentuk tindakan pencegahan primer (Windiana, 2015). Sedangkan menurut Isro'in dan Andarmoyo (2012), Higiene personal adalah suatu tindakan untuk memelihara kebersihan dan kesehatan seseorang untuk kesejahteraan baik fisik maupun psikisnya. Perilaku higiene personal yang baik akan meminimalkan pintu masuk mikroorganisme sehingga dengan minimnya mikroorganisme diharapkan dapat meminimalkan resiko individu terkena penyakit. Contoh higiene yang diterapkan dalam kehidupan sehari-hari seperti mencuci tangan, mandi, mencuci baju dan mencuci alat-alat rumah tangga lain setelah digunakan (Windiana, 2015).

Tujuan penelitian ini adalah untuk mengetahui sejauh mana tingkat kepatuhan dan tingkat kesadaran masyarakat dalam melaksanakan dan menyikapi aturan yang telah 
Prosiding Seminar Nasional Pembangunan dan Pendidikan Vokasi Pertanian

Politeknik Pembangunan Pertanian Manokwari, 14 November 2020

e ISSN : 2774-1982

dikeluarkan oleh pemerintah khususnya dalam hal penerapan higiene personal pada saat proses penyembelihan hewan qurban dimasa pandemik covid 19.

\section{METODE}

\section{Waktu dan Tempat Penelitian}

Penelitian ini dilaksanakan selama 3 (tiga) hari, mulai tanggal 31 Juli sampai dengan 2 Agustus 2020 yang belokasi di 30 masjid yang ada di wilayah Kabupaten Manokwari Provinsi Papua Barat.

\section{Alat dan Bahan Penelitian}

Alat dan bahan yang digunakan dalam penelitian ini adalah kelengkapan yang dibutuhkan dalam proses pengambilan data penelitian seperti alat tulis menulis, kamera, quisioner dan tanda pengenal.

\section{Metode Penelitian}

Aspek higiene personal yang digunakan dalam penelitian ini mengacu pada SE yang dikeluarkan oleh Kementerian Pertanian melalui Dinas Pertanian dan Ketahanan Pangan Kabupaten Manokwari. Aspek tersebut meliputi: 1. Petugas di area penyembelihan dan petugas penanganan daging dan jeroan, 2. Pengunaan masker/ faceshield pada saat menangani daging qurban, 3. Pengunaan sarung tangan sekali pakai pada saat menangani daging qurban, 4. ketersediaan sarana cuci tangan yang dilengkapi dengan detergen/ sabun/ hand sanitizer dilokasi penyembelihan,5. Cuci tangan pake sabun dan 6. Saling berjabat tangan antara satu dengan yang lainnya. Keenam aspek tersebut (A1, A2, A3, A4, A5 dan A6) dituangkan dalam bentuk quisioner dan selajutnya dibagikan kepada masing-masing petugas yang telah ditentukan sebelumnya.

\section{Analisis Data}

Data yang diperoleh pada saat penelitian selanjutnya akan dianalisis secara deskriptif kuantitatif berdasarkan hasil pengamatan dilapangan

\section{HASIL DAN PEMBAHASAN}

Penyembelihan hewan qurban merupakan aktivitas penyembelihan hewan ruminansia yang mayoritas dilakukan diluar Rumah Potong Hewan (RPH). Fasilitas dalam penyembelihan hewan qurban di masjid-masjid umumnya tidak selengkap di RPH dan biasanya cenderung menggunakan peralatan dan perlengkapan seadanya. Demikian pula personel yang terlibat, sebagian besar belum terlatih untuk menyembelih hewan (Winarso dkk, 2018). Proses penyembelihan yang dilakukan diluar RPH juga membutuhkan 
Prosiding Seminar Nasional Pembangunan dan Pendidikan Vokasi Pertanian

Politeknik Pembangunan Pertanian Manokwari, 14 November 2020

e ISSN : 2774-1982

pengawasan dan perhatian khusus dari semua pihak mengingat proses penyembelihan yang dilakukan pada tahun 2020 dilaksanakan ditengah situasi pandemi covid 19.

Untuk mencegah penyebaran dan untuk memutus rantai penyebaran covid 19, Pemerintah Pusat melalui Kementerin Pertanian telah mengeluarkan Surat Edaran Nomor. 0008. SE/PK.320/F/06/2020 Tentang Pelaksanaan Kegiatan qurban dalam Situasi Wabah Bencana Nonalam Corona Virus Disease (Covid 19). Salah satu yang tertuang dalam Surat Edaran tersebut adalah tentang pentingnya penerapan higiene personal dalam pelaksanaan penyembelihan hewan qurban di tengan pandemi Covid 19.

Tabel 1. Aspek pengukuran

\begin{tabular}{cccc}
\hline $\begin{array}{c}\text { Jumlah Sampel } \\
\text { (Masjid) }\end{array}$ & Aspek Yang Diukur & Ya & Tidak \\
\hline & A1 & 24 & 6 \\
A2 & 4 & 26 \\
30 & A3 & 8 & 22 \\
& A4 & 10 & 20 \\
A5 & 5 & 25 \\
A6 & 16 & 14 \\
\hline
\end{tabular}

Berdasarkan data pada tebel 1 diketahui bahwa 24 masjid dari 30 masjid yang digunakan sebagai sampel penelitian, petugas penanganan daging dengan petugas penanganan jeroan masih sama (gambar 1). Marriott (1997), menyatakan bahwa jika petugas tidak menerapkan higiene personal dengan baik dan tidak dibedakan antara petugas diarea bersih dan area kotor pada saat penyembelihan dan penanganan daging maka akan sangat berpotensi untuk menjadi sumber pencemaran pada produk daging yang dihasilkan dimana kualitasnya akan turun. Kejadian seperti ini sebaiknya dihindari mengingat pada era new normal saat ini masyarakat membutuhkan makanan yang tidak hanya bergizi untuk menjaga imunitasnya dalam menghadapi penyebaran virus COVID19, namun juga perlu makanan yang aman untuk dikonsumsi.

Dalam hal kedisiplinan pemakaian masker/ faceshield dan pemakaian sarung tangan sekali pakai dalam menangani daging qurban juga menunjukkan data yang tidak jauh berbeda yaitu sebanyak 26 dan 22 masjid dari 30 masjid yang digunakan sebagai sampel dalam penelitian, panitia dan petugas pelaksana penyembelihan hewan qurban masih tidak memakai masker / faceshield dan sarung tangan sekali pakai (gambar 2). 

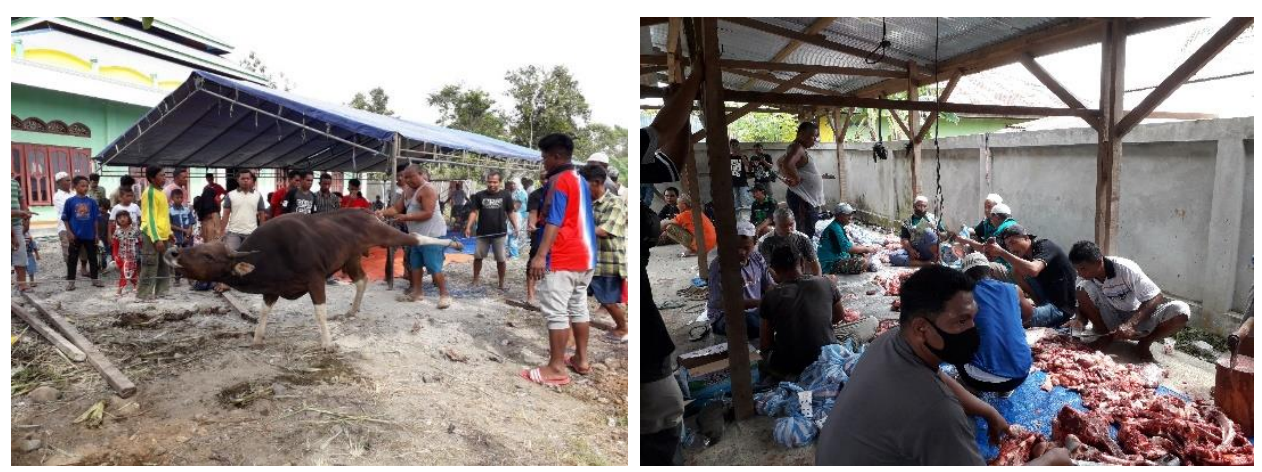

Gambar 1. Petugas di area penyembelihan dan petugas penanganan daging dan jeroan masih sama

Hal ini menunjukkan bahwa tingkat kesadaran masyarakat khususnya panitia atau petugas pelaksana penyembelihan hewan dan penanganan daging qurban akan pentingnya menjaga kesehatan dan kebersihan terutama pencegahan terhadap adanya potensi penularan covid 19 masih rendah. Selain faktor kesadaran, tingkat pemahaman masyarakat akan pentingnya higiene personal dalam menentukan kualitas daging yang dihasilkan juga masih belum sepenuhnya dipahami. Menurut Hariyadi dan Ratih (2009), Penanganan daging yang kurang baik dan tidak higienis akan berdampak terhadap kehalalan, mutu dan keamanan daging yang dihasilkan dan akan berdampak negatif pada kesehatan masyarakat.
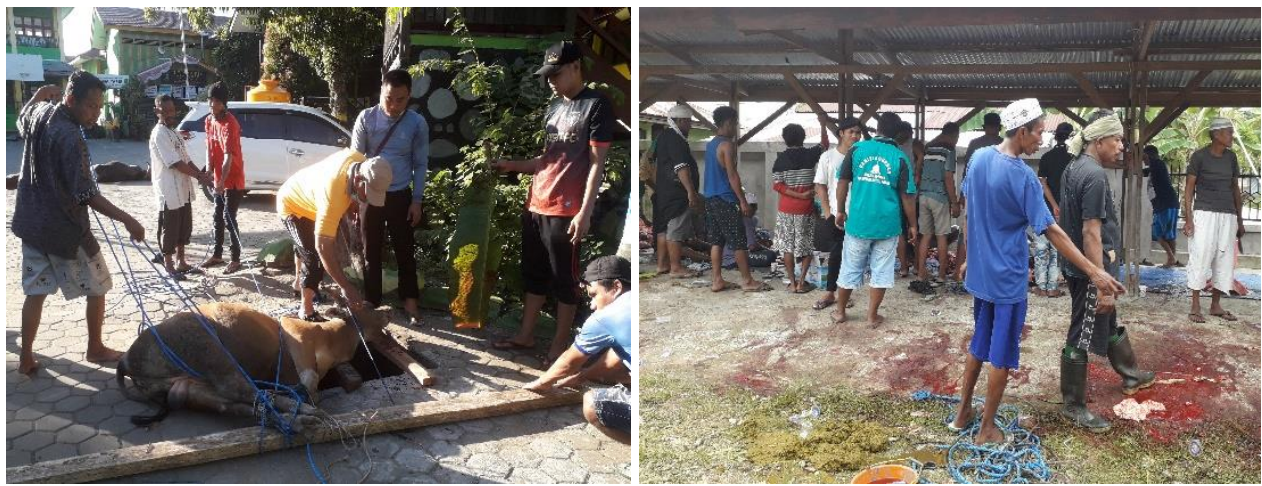

Gambar 2. Panitia dan petugas pelaksana tidak menggunakan masker dan sarung tangan sekali pakai

Berdasarkan ketersediaan sarana cuci tangan yang dilengkapi dengan desinfektan/sabun, sekitar 20 masjid dari 30 masjid yang digunakan sebagai sampel penelitian juga belum menyediakan fasilitas yang dikhususkan untuk cuci tangan. Dari 10 masjid yang menyediakan fasilitas cuci tangan hanya 5 masjid yang sudah dilengkapi dengan fasilitas desinfektan/ sabun sehingga hal ini sangat berpengaruh terhadap respon atau keinginan dari petugas pelaksana penyembelihan dan penanganan daging qurban untuk melakukan cuci tangan dengan menggunakan desinfektan/sabun. Umumnya petugas 
Prosiding Seminar Nasional Pembangunan dan Pendidikan Vokasi Pertanian Politeknik Pembangunan Pertanian Manokwari, 14 November 2020

e ISSN : 2774-1982

pelaksana penyembelihan dan petugas penanganan daging qurban melakukan cuci tangan dengan menggunakan air yang telah ditampung di dalam ember-ember ataupun dengan mengalirkan air langsung dengan menggunakan selang tanpa menggunakan desinfektan.

Cuci tangan pakai sabun (CTPS) adalah salah satu tindakan sanitasi dengan membersihkan tangan dan jari-jemari menggunakan air dan sabun sehingga menjadi bersih. Cuci tangan pakai sabun merupakan cara yang sederhana, mudah, dan bermanfaat untuk mencegah berbagai penyakit seperti cacingan, diare, hepatitis, (Infeksi Saluran Pernapasan Akut (ISPA) maupun penyakit yang disebabkan oleh agen infeksius lainnya (Natsir, 2018). Cuci tangan pakai sabun yang dipraktikkan secara tepat dan benar merupakan cara termudah dan efektif untuk mencegah berjangkitnya suatu penyakit (Desiyanto dan Djannah, 2012).
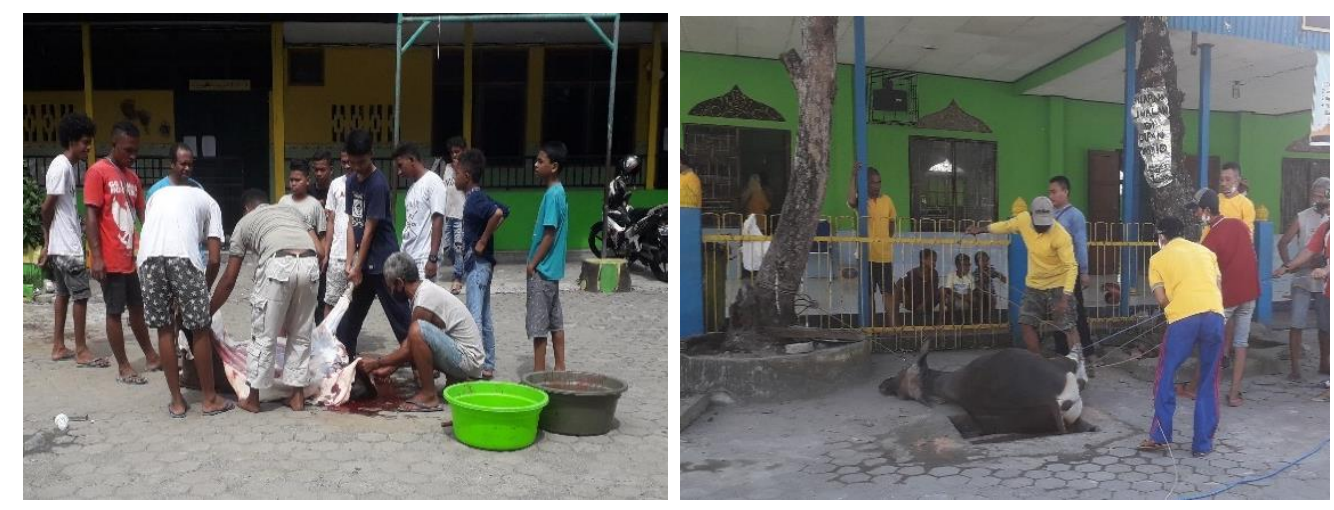

Gambar 3. Belum tersedianya sarana cuci tangan yang dilengkapi dengan desinfektan dan hanya tersedia air yang ditampung di ember- ember kecil

Kebiasaan berjabat tangan ketika bertemu juga masih dilakukan dan sulit untuk dihilangngkan. Hal ini karena berjabat tangan merupakan kebiasaan yang sudah dilakukan secara turun temurun dari nenek moyang dan sudan menjadi tradisi yang melekat di kalangan masyarakat di Indonesia. Selain alasan diatas, nampaknya masyarakat khususnya di Kabupaten Manokwari masih menganggab biasa terhadap adanya kejadian wabah covid 19 sehingga walaupun pemerintah telah mengeluarkan surat edaran yang mengatur tentang tata cara penyembelihan dan penangan daging qurban di tengah pandemi covid 19 sebagian besar masyarakat masih belum mematuhinya. Hal ini terlihat berdasarkan hasil data penelitian pada tabel diatas dimana dari 30 lokasi masjid, hanya 5 lokasi masjid dimana panitia, petugas dan masyarakatnya tidak melakukan jabat tangan ketika ada dilokasi penyembelihan dan penanganan daging qurban. 
Prosiding Seminar Nasional Pembangunan dan Pendidikan Vokasi Pertanian

Politeknik Pembangunan Pertanian Manokwari, 14 November 2020

e ISSN : 2774-1982

\section{KESIMPULAN DAN SARAN}

Berdasarkan hasil dan pembahasan maka penelitian ini dapat disimpulkan bahwa sebagian besar masjid yang ada di wilayah Kabupaten Manokwari belum menerapkan aspek higiene personal pada saat sebelum proses penyembelihan, saat proses penyembelihan dan saat penanganan daging qurban. Hal ini menunjukkan bahwa tingkat kepatuhan dan tingkat kesadaran masyarakat dalam melaksanakan dan menyikapi aturan yang telah dikeluarkan oleh pemerintah khususnya dalam hal penerapan higiene personal masih rendah.

\section{DAFTAR PUSTAKA}

Desiyanto \& Djannah. (2013). Efektifitas Mencuci Tangan Menggunakan Cairan Pembersih Tangan Antiseptik (Hand Sanitizer) Terhadap Jumlah Angka Kuman, Jurnal Kesehatan Masyarakat, Vol.2 No.2.

Dirjennak. (2020). Surat Edaran No. 0008. SE/PK.320/F/06/2020 Tentang Pelaksanaan Kegiatan Kurban dalam Situasi Wabah Bencana Nonalam Corona Virus Disease (Covid 19). Kementerian Pertanian. Jakarta.

Hariyadi \& Ratih. (2009). Memproduksi Pangan yang Aman. Dian Rakyat. Jakarta.

Isro'in L \& Andarmoyo S. (2012). Personal Hygiene. Cetakan I Graha Ilmu. Yogyakarta.

Marriott N.G. (1997). Essentials of Food Sanitation. Chapman and Hall. New York.

Winarso A, Darmakusuma D, \& Sanam M.U.E. (2018). Promosi kesejahteraan hewan dan higiene sanitasi dalam penyembelihan hewan kurban di Kota Kupang. ARSHI Vet Lett, IPB. Bogor.

Windiana D. Muda I. Indrawati R. Putra W.W. Supratikno \& Asnawi. (2015). Menerapkan Higiene Sanitasi. Pusat Pelatihan Pertanian. Jakarta.

Natsir, M.H. (2018). Pengaruh Penyuluhan Ctps Terhadap Peningkatan Pengetahuan Siswa Sdn 169 Bonto Parang Kabupaten Jeneponto. Jurnal Nasional Ilmu Kesehatan (Jnik) Lp2m Unhas, Vol 1, 2. 